UDC 316.34

DOI: $10.21668 /$ health.risk/2021.3.11.eng

Research article

\title{
SOCIETAL DETERMINANTS OF HIV-INFECTION SPREAD IN REGIONS IN THE RUSSIAN FEDERATION
}

\section{S.I. Boyarkina, D.K. Khodorenko}

Sociological Institute of the RAS - Branch of the Federal Center of Theoretical and Applied Sociology of the Russian Academy of Sciences, 25/14 7th Krasnoarmeyskaya Str., St. Petersburg, 190005, Russian Federation

The paper dwells on the results obtained via examining dependence between HIV-infection spread and factors related to social environmental and social structure of population in RF regions. These factors are considered to be potential health risk ones. The authors tested a hypothesis about influence exerted by demographic, economic, cultural and behavioral determinants and public healthcare availability on differences in territorial spread of the disease within social epidemiologic approach.

To solve the set task, data that characterized 85 RF regions were taken from official statistical reports. Descriptive statistic analysis was performed and regression models were built up; it allowed testing whether the analyzed factors had their influence in $R F$ regions and selecting the most significant ones to be included into the overall regression model.

The research revealed significant contextual differences in HIV-infection spread. Regression analysis showed that $22.0 \%$ differences in a number of HIV-infected people detected in RF regions occurred due to differences in urban population numbers, provision with ambulatories and polyclinics, and unemployment rate. Moreover, a number of registered crimes committed by minors determined $32.5 \%$ difference in a number of patients with the first diagnosed HIV-infection between the examined regions.

These results allow assuming that the greatest influence on spread of the disease in RF regions is exerted by consequences of urbanization; this process is usually accompanied with a growth in a share of urban population in a given region, instability on the labor market there as well as related migration processes within the country and wider opportunities to pursue individual behavioral strategies including those that involve law violations and/or are destructive for people's health.

Key words: inequalities in health, societal determinants, HIV-infection spread, regions in the Russian Federation, mathematical modeling, regression analysis.

Introduction. Spread of socially significant diseases, just as health in general, is influenced by inequalities appearing at any level in society organization; institutional factors, material world, cultural, behavioral, individual socio-psychological and status determinants; the most significant effects are usually produced by income, education, and employment. Higher social status secures better access to vital resources that are necessary to preserve health and results in health inequalities and uneven distribution of risks related to morbidity and premature mortality in a society [1].

There are two basic approaches to examining social inequalities in health that are usu- ally described in foreign theoretical reviews. The first one (1) is an objectivist approach that is being developed predominantly within social epidemiology and social sciences. This approach assumes that differences in people' health are determined by the environment with its material, cultural, and institutional parameters and not by people's individual psychological and behavioral peculiarities. The second approach (2) is subjectivist and is based on opinions by medical experts and experts in psychology who claim that there are differences in psychological and behavioral reactions and resistance that help people to cope with stresses and diseases successfully using

(C) Boyarkina S.I., Khodorenko D.K., 2021

Saniya I. Boyarkina - Candidate of Sociological Sciences, Assistant Professor, Senior Researcher (e-mail: s.boyarkina@socinst.ru; tel.: +7 (812) 316-24-96; ORCID: https://orcid.org/0000-0002-3944-0076).

Daria K. Khodorenko - Junior Researcher (e-mail: khodasha@gmail.com; tel.: +7 (812) 316-24-96; ORCID: https://orcid.org/0000-0001-7162-7511). 
their individual psychological resources and support provided by social environment. Explanatory mathematical models have been developed within these two approaches; they provide an opportunity to analyze influence exerted on health by material factors, cultural and behavioral parameters as well as individual socio-psychological ones, specific procedures to estimate social status; these models also allow analyzing how inequalities in health occur and reproduce themselves both in a cross-sectional measuring in specific social groups and in longitude one over a whole life time [2].

Experts who accomplished their research within these approaches put forward a hypothesis that was based on accumulated knowledge and concentrated on a role played by biological (genetic) environmental, socialstructural and individual factors in spread of diseases in various social groups. The hypothesis was repeatedly corroborated in social and epidemiological studies that focused on analyzing existing material and cultural factors; social processes that create conditions for health inequalities to occur; and factors of economic well- (ill) -being (first of all, poverty and related issue of medical aid availability), living conditions, nutrition, negative psychological influences and related behavioral patterns regarding health. Social epidemiologic approach provided convincing evidence that health inequalities depended on the aforementioned reasons and thus dominated in studies focusing on health inequalities approximately up to late 1990 s - early $2000 s^{1}[1,3-6]$ and is still relevant. Social production of health / diseases and multilevel ecosocial theory of disease have been developed within it.

Multilevel methodology that is now applied by researchers helps estimate influences exerted on health by both individual determinants and structural and contextual ones. It has been repeatedly corroborated in empirical re- search that differences in morbidity and mortality are caused not so much by individual psychological and behavioral peculiarities as by material, cultural and institutional parameters of the environment [7]. And still most research papers that have been published by Western scientists over the last 15 years focus on examining social-structural and behavioral factors. Effects produced by social context factors have not been studied so profoundly although they are the most significant ones when it comes down to an insight into social mechanisms of diseases occurrence and their dependence on global social processes ${ }^{2}$.

Although significance of issues related to social inequalities in health is hardly disputable, in Russia there have also been few studies on health being dependent on social parameters of macrocontext; it calls for a necessity to reveal factors that exert the greatest influence on spread of socially significant diseases.

According to statistic data provided by the RF Public Healthcare Ministry, The RF Labor Ministry, and Rosstat, HIV-infection caused by human immunodeficiency virus has been among the most frequently registered socially significant diseases in Russia over the last decades) ${ }^{3}$. A number of registered people with HIV-infection at the end of a calendar year minus those who have died over the same year is an indicator that shows prevalence of the disease in a given region and it is a significant analytical parameter used to comparatively assess territorial peculiarities related to spread of the disease.

Test of basic hypotheses formulated within social epidemiologic approach regarding peculiarities of territorial HIV-infection prevalence reveals common regularities in spread of the disease in the Russian Federation and allows making assumptions on reasons for existing differences between regions. This can give grounds for further development of target measures within social policy aimed at optimizing an epidemic situation in regions.

\footnotetext{
${ }^{1}$ Doyal L., Imogen P. The political economy of health. London, Pluto Press, 1979, 360 p.

${ }^{2}$ Krickeberg K., Klemperer D. Modern Infectious Disease Epidemiology: Concepts, Methods, Mathematical Models, and Public Health. In: A. Krämer, M. Kretzschmar, K. Krickebergeds eds. New York, Springer Publ., 2010, 443 p.

${ }^{3}$ Zdravookhranenie v Rossii. 2019: stat. sb. [Public healthcare in Russia. 2019: statistical data collection]. Federal State Statistic Service. Available at: https://rosstat.gov.ru/storage/mediabank/Zdravoohran-2019.pdf (March 01, 2021) (in Russian).
} 
Data and methods. A possibility to perform analysis that would correspond to the fixed tasks was limited by available statistical data on relevant macrocontext parameters in regions in Russia. Therefore, we examined data on these parameters collected in 2017 since they were the most completed in a database created by the Federal State Statistic Service.

In the RF over the last 15 years epidemiological situation regarding $\mathrm{HIV}$-infection has been deteriorating [8]. As of December 31, 2017 a cumulative number of registered HIVinfection cases amounted to $1,220,659$ people $^{4}$ among the RF citizens. At the end of 2017 more than 943,999 people in Russia had HIVinfection, 276,660 deceased patients excluded. In 2017 morbidity amounted to 71.1 cases per 100 thousand people (it was 69.6 in 2016). There were several regions where morbidity was higher than on average in the country and they became leaders as per this parameter. These regions included Kemerovo region (203.0 new registered HIV cases per 100 thousand people), Irkutsk region (160.7), Sverdlovsk region (157.2), Chelyabinsk region
(154.0), Novosibirsk region (142.8) Perm region (140.8), Tyumen region (138.7), Tomsk region (128.2), Kurgan region (117.3), Orenburg region (114.7), Krasnoyarsk region (114.1), Khanty-Mansi Autonomous Area (109.2), Samara region (105.0), Omsk region (103.9), Altai region (101.5), Ulyanovsk region (93.9), Crimea (88.1), Udmurtia (87.4), Khakass Republic (84.4), Sevastopol (73.5), Moscow region (73.4), and Nizhniy Novgorod region (72.3) области.

Preliminary analysis of descriptive statistics on all regions in Russia in 2017 allows stating there are apparent territorial differences in HIV-infection spread (Figure 1).

We reviewed research papers that focused on explaining differences in morbidity with socially significant diseases among population in different countries in the world; it allowed us to spot out several key determinants at macro-level influencing spread of socially significant diseases. These are demographic factors, factors related to socioeconomic development including GDP (gross domestic product) and Gini coefficient (it shows income

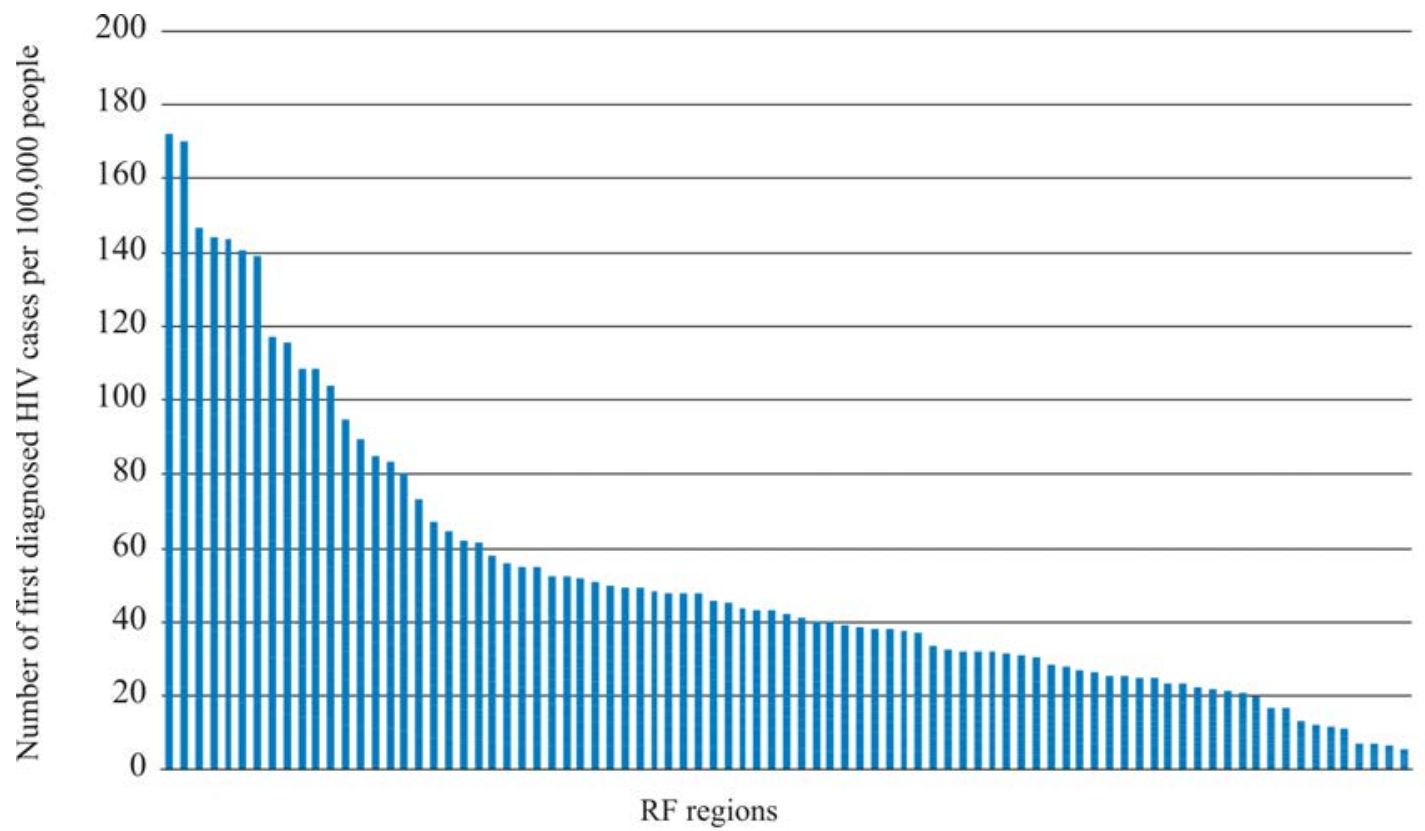

Figure 1. RF regions distributed as per a number of patients with first diagnosed HIV

\footnotetext{
${ }^{4}$ Spravka VICh-infektsiya v Rossiiskoi Federatsii v pervom polugodii 2019 g. [Reference to HIV-infection in the Russian Federation in the first half of 2019]. Available at: https://aids-centr.perm.ru/images/4/hiv_in_russia/hiv_in_rf_30.06.2019.pdf (March 01, 2021) (in Russian).
} 
inequality), labor market parameters; social and political parameters of a society in a country and its functioning including social policies in education and public healthcare, expenses on public healthcare and provision with medical aid; factors related to social structure of a society including incomes, education, and occupation; cultural and behavioral determinants like prevalence of health-destructive behavioral patterns, crime rate, etc.

These and some other parameters can be used to estimate reasons for spread of socially significant diseases in regions in the Russian Federation and to examine regional differences [9].

To solve the task, we took regional statistic data on $85 \mathrm{RF}$ regions from official statistic sources. When creating a database, we selected the following groups of parameters: demographic (population number in a given region, men to women ratio, specific weight of urban and rural population in the overall population number, people older than working age, migration growth rate); socioeconomic (Gini coefficient, gross regional product per capita, average floor area per person, a number of private passenger cars per 1,000 people, number of unemployed among people aged 15-72, unemployment rate); social and political (medical aid availability (number of in-patient beds per 10,000 people, a number of people per an inpatient bed, capacities of out-patient polyclinics, number of physicians with all specialties)); social and structural (number of people with incomes lower than living wage, number of specialists with higher education who chose teaching at a higher education establishment as a career after graduation in 2017); cultural and behavioral (number of registered crimes per 100 thousand people, a number of registered crimes committed by minors per 100 thousand people, number of patients with first diagnosed drug addiction who were subject to obligatory dispensary observation per 100 thousand people).
We applied a multiple linear regression to statistically analyze the selected data; the regression was calculated as per the following formula:

$$
\gamma=\beta_{0}+\beta_{1} X_{1}+\ldots+\beta_{n} X_{n}+e,
$$

where $\gamma$ is the dependent variable showing "a number of patients with first diagnosed HIV per 100 thousand people"; $\beta_{0}$ is the constant (intercept); $X_{1} \ldots X_{n}$ are the independent variables showing regional parameters that probably influence morbidity with HIV-infection in a given region; $e$ is unexplained residuals in regression. We analyzed correlations between HIV-infection prevalence and demographic, socioeconomic, social and political, social and structural, and cultural and behavioral parameters of the RF regions. Several regression models were built up to test influence exerted by each group of regional parameters and the most significant factors were selected among them to be included into the generalized linear model. Regression analysis involved step-bystep testing of influence exerted by different groups of parameters on HIV-prevalence in regions and building up the generalized model. To facilitate analysis, all the variables were standardized (transformed into Z-score) to provide correct comparison of regression coefficients. This procedure for data analysis allows selecting factors that are stronger correlated with spread of the disease and revealing key regional parameters that determine health inequalities among population living there.

Results and discussion. Table 1 contains minimum, maximum and average values and standard deviations for regional parameters that turned out to be statistically significant in regression analysis. Other factors also had certain influence; it was examined in regression analysis and turned out to be insignificant, so, descriptive statistic values for such factors were not included into the Table ${ }^{5}$. A number

\footnotetext{
${ }^{5}$ These parameters in 2017 included the following: men to women ratio (estimated at the end of the year; a number of women per 1,000 men) in a region, a share of population in their working age; a number of population of their income being lower than living wage; Gini coefficient; gross regional product per capita, a number of physicians per 10 thousand people; a number of people per one physician; a number of in-patient beds per 10 thousand people; migration growth rate; a number of registered crimes per 100 thousand people; a number of private passenger cars per 1,000 people; a number of drug addicts per 100 thousand people in a corresponding population group.
} 
Table 1

Descriptive statistic values for parameters characterizing regions in the RF

\begin{tabular}{|c|c|c|c|c|}
\hline Parameter & Minimum & Maximum & Average & $\begin{array}{l}\text { Standard } \\
\text { deviation }\end{array}$ \\
\hline $\begin{array}{l}\text { Number of patients with first diagnosed HIV per } 100 \text { thousand } \\
\text { people in } 2017\end{array}$ & 5.4 & 172.3 & 52.8 & 39.1 \\
\hline A share of urban population in a region in $2017, \%$ & 29.0 & 100.0 & 70.5 & 13.2 \\
\hline A number of unemployed people aged $15-72$, thousand people & 1.0 & 163.0 & 46.6 & 35.3 \\
\hline $\begin{array}{l}\text { A number of registered crimes committed by minors per } 100 \\
\text { thousand people }\end{array}$ & 14.0 & 2107.0 & 530.1 & 428.7 \\
\hline Provision with out-patient polyclinics per 10 thousand people & 124.9 & 507.6 & 277.0 & 54.2 \\
\hline
\end{tabular}

Table 2

A correlation between a number of patients with first diagnosed HIV per 100 thousand people in 2017 and regional parameters

\begin{tabular}{|l|c|c|c|c|}
\hline \multicolumn{1}{|c|}{ Parameter } & $\begin{array}{c}\text { Demographic } \\
\text { factors } \\
\text { Model 1 }\end{array}$ & $\begin{array}{c}\text { Economic } \\
\text { factors } \\
\text { Model 2 }\end{array}$ & $\begin{array}{c}\text { Medical aid } \\
\text { availability } \\
\text { Model 3 }\end{array}$ & $\begin{array}{c}\text { Cultural and behav- } \\
\text { ioral factors } \\
\text { Model 4 }\end{array}$ \\
\hline Constant (intercept) & $\begin{array}{c}5.285 \mathrm{E}-16 \\
(0.104)\end{array}$ & $\begin{array}{c}2.025 \mathrm{E}-16 \\
(105)\end{array}$ & $\begin{array}{c}-3.725 \mathrm{E}-16 \\
(107)\end{array}$ & $\begin{array}{c}5.5031 \mathrm{E}-16 \\
(0.088)\end{array}$ \\
\hline $\begin{array}{l}\text { Specific weight of urban population in total } \\
\text { population }\end{array}$ & $\begin{array}{c}0.31(0.104) \\
* * *\end{array}$ & & & \\
\hline A number of unemployed people aged 15-72 & & $0.27(0.106)^{*}$ & & \\
\hline $\begin{array}{l}\text { Provision with out-patient polyclinics per } \\
\text { 10,000 people }\end{array}$ & & & $0.21(0.108)$ & \\
\hline $\begin{array}{l}\text { A number of registered crimes committed by } \\
\text { minors per 100 thousand people }\end{array}$ & & & & $0.59(0.088) * * *$ \\
\hline $\boldsymbol{R}^{2}$ & $\mathbf{0 . 0 9 6}$ & $\mathbf{0 . 0 7 1}$ & $\mathbf{0 . 0 4 1}$ & $\mathbf{0 . 3 5 2}$ \\
\hline Adjusted R Square & $\mathbf{0 . 0 8 5}$ & $\mathbf{0 . 0 6}$ & $\mathbf{0 . 0 2 9}$ & $\mathbf{0 . 3 4 4}$ \\
\hline $\boldsymbol{F}$ & $\mathbf{8 . 8 4 6 * * *}$ & $\mathbf{6 . 3 7 9 *}$ & $\mathbf{3 . 5 1}$ & $\mathbf{4 5 . 1 1 * * *}$ \\
\hline
\end{tabular}

$\mathrm{N}$ o t e : *** means $p<0.001 ; * *$ means $p<0.01 ; *$ means $p<0.05$; means $p<0.1 . \beta(\mathrm{SE})$ for each factor are given in the Table.

of patients with first diagnosed HIV per 100 thousand people differed in different regions in 2017 starting from 5.4 and up to 172.3 cases per 100 thousand people. This value is a dependent variable. A share of urban population varied from $29 \%$ to $100 \%$. For example, federal cities (Saint Petersburg, Moscow, and Sevastopol) and northern regions (Magadan region and Murmansk region) had the greatest share of urban population. This share was minimal in such regions as Altai Republic, Chechnya, and Karachai-Cherkess Republic. A number of unemployed people aged 15-72 varied from 1,000 to 163,000 . The lowest numbers were detected in Chukotka, Nenets Autonomous Area, and Magadan region; the greatest numbers, in Dagestan, Moscow region, and Krasnodar region. A number of reg- istered crimes committed by minors per 100 thousand people was the highest in Irkutsk region, Chelyabinsk region, and Sverdlovsk region. The lowest numbers of such crimes were registered in Ingushetia, Chechnya, and Chukotka. The minimum value of the parameter was 14 cases, and the maximum, 2,107 cases per 100 thousand people. Provision with outpatient polyclinics per 10,000 people was the best in Chukotka, Magadan region, and Komi Republic. The smallest numbers of such polyclinics per 10,000 people were detected in Chechnya, Ingushetia, and Dagestan.

Results obtained at the first stage in regression analysis are given in Table 2 .

Model 1 was built to test an assumption that demographic parameters in a region had certain influence on a number of patients with 
first diagnosed HIV per 100 thousand people (Figure 2).

The model included the following independent variables: specific weight of urban population in total population, men to women ration (estimated at the end of the year), a share of population in working age, and migration growth rate. Significant positive correlation was detected only with specific weight of urban population $(0.31 ; p<0.001)$ and this indicates that $\mathrm{HIV}$-infections spreads predominantly among urban population.

Model 2 was created to test correlations between parameters related to medical aid availability in regions and a number of patients with first diagnosed HIV-infection. To test influence exerted by medical aid availability in regions on the dependent variable, we used the following parameters of regional healthcare systems: provision with out-patient polyclinics per 10 thousand people, a number of physicians per 10 thousand people, a number of people per one physician, and a number of inpatients bed per 10 thousand people. We revealed that there was only one statistically significant correlation in the model, between HIV prevalence and a number of out-patient polyclinics per 10 thousand people $(0.21 ; p<0.1)$ (Figure 3).

Model 3 was used to test correlations between economic factors and HIV-infection prevalence. We tested correlations between prevalence of the infection and a number of unemployed people aged 15-72, number of people with their incomes being lower than living wage, Gini coefficient, gross regional product per capita, a number of private passenger cars per 1,000 people, and average floor area per person. A statistically significant correlation was detected between HIV prevalence in a region and a number of unemployed people aged $15-72(0.27 ; p<0.05)$ (Figure 4).

To test correlation between HIV prevalence and cultural and behavioral factors, we analyzed the following variables in the model: a number of specialists with higher education who chose teaching at a higher education establishment as a career after graduation, a number of registered crimes per 100 thousand

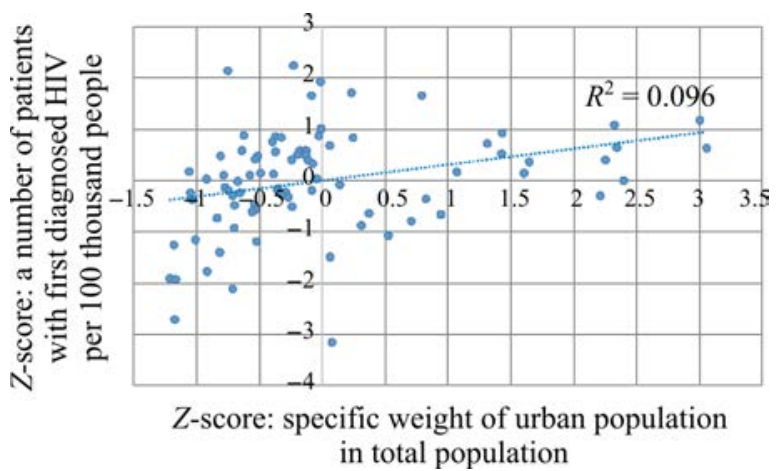

Figure 2. A correlation between a number of patients with first diagnosed HIV per 100 thousand people and specific weight of urban population in total population

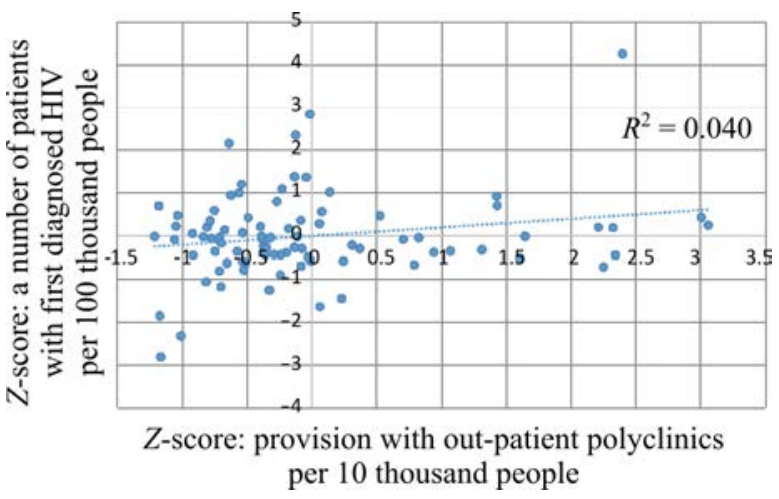

Figure 3. A correlation between number of patients with first diagnosed HIV per 100 thousand people and medical aid availability in RF regions

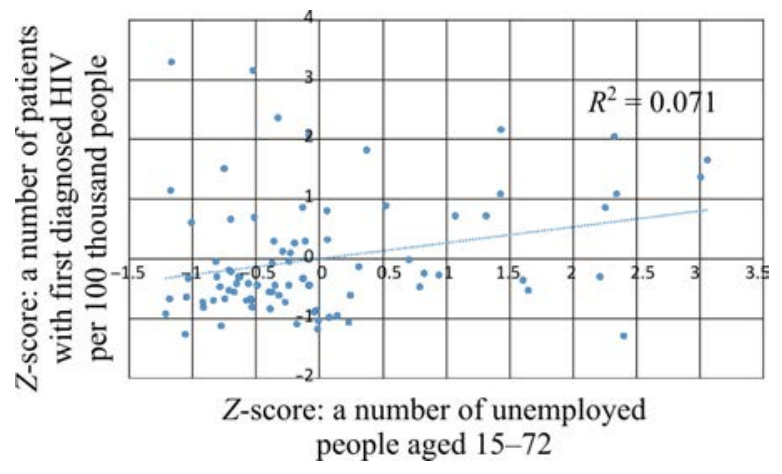

Figure 4. A correlation between number of patients with first diagnosed HIV per 100 thousand people and a number of unemployed people aged 15-72

people, a number of registered crimes committed by minors per 100 thousand people, a number of patients with first diagnosed drug addiction who were subject to obligatory dispensary observation per 100 thousand people). We detected that a number of drug addicts correlated with a number of HIV-infected patients. 
However, this factor loses its significance when it is included into regression together with unemployment rate. So, we can assume that unemployment can cause both HIV spread and a growing number of patients with drug addiction. As a result, only a number of registered crimes committed by minors per 100 thousand people turned out to be significant in the created model $(0.59 ; p<0.001)$ (Figure 5).

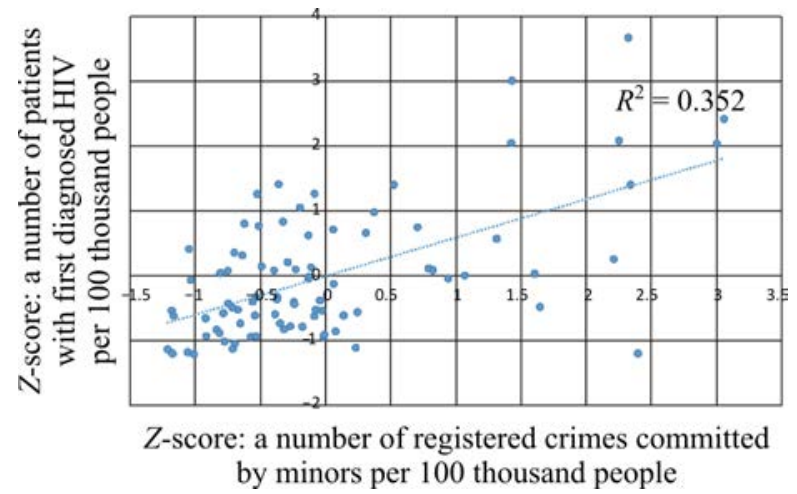

Figure 5. A correlation between a number of patients with first diagnosed HIV per 100 thousand people and a number of registered crimes committed by minors

A number of registered crimes committed by minors plays an important role in HIV prevalence in a region. When this parameter is included into the generalized linear model simultaneously with other factors (a share of urban population, a number of unemployed people, and a number of out-patient polyclinics), it results in occurring multicollinearity. This occurs due to a strong correlation between crimes committed by minors and a number of unemployed people aged 15-72 (correlation coefficient amounts to 0.685 for these two parameters; $p<0.001)$. To resolve the issue with multicollinearity, two models were built; one of them included unemployment rate, and another, a number of crimes committed by minors (Table 3).

Generalized linear model 1 included such regional parameters as specific weight of urban population in total population $(0.24 ; p<0.05)$, a number of unemployed aged 15-72 (0.36; $p<0.001$ ), and provision with out-patient polyclinics $(0.25 ; p<0.05)$. They were all significantly correlated to the dependent variable: there were higher numbers of patients with first diagnosed HIV in regions with high shares of urban population, unemployment rate, and a number of out-patient polyclinics. It is these factors that explain $22.0 \%$ of variations between regions in a number of patients with first diagnosed HIV.

Generalized linear model 2 included only one parameter, a number of registered crimes committed by minors per 100 thousand people. A share of explained variations in a number of patients with first diagnosed HIV amounted to $35.2 \%$ in this model.

Regression analysis revealed that a number of HIV-infected people registered in RF regions correlated with a share of urban population in a given region, provision with outpatient polyclinics, a number of unemployed, and a number of registered crimes committed by minors (parameters are given in an ascending order for correlation strength). The latter

Table 3

Generalized linear models

\begin{tabular}{|l|c|c|}
\hline \multicolumn{1}{|c|}{ Parameter } & Generalized model 1 & Generalized model 2 \\
\hline Constant (intercept) & $9.6514 \mathrm{E}-17(0.098)$ & $5.5031 \mathrm{E}-16^{* * *}$ \\
\hline Specific weight of urban population in total population & $0.24^{*}(0.104)$ & \\
\hline A number of unemployed people aged 15-72 & $0.36^{* * *}(0.105)$ & \\
\hline Provision with out-patient polyclinics per 10,000 people & $0.25^{*}(0.111)$ & \\
\hline $\begin{array}{l}\text { A number of registered crimes committed by minors } \\
\text { per 100 thousand people }\end{array}$ & & $0.59(0.088)^{* * *}$ \\
\hline $\boldsymbol{R}^{2}$ & $\mathbf{0 . 2 2}$ & $\mathbf{0 . 3 5 2}$ \\
\hline Adjusted R Square & $\mathbf{0 . 1 9}$ & $\mathbf{0 . 3 4 4}$ \\
\hline $\boldsymbol{F}$ & $\mathbf{7 . 5 8} * * * *$ & $\mathbf{4 5 . 1 1}^{* * *}$ \\
\hline
\end{tabular}

Note: *** means $p<0.001$; ** means $p<0.01$; ${ }^{*}$ means $p<0.05$; means $p<0.1$. $\beta$ (SE) are given for each factor in the Table. 
two parameters (unemployment and a number of crimes committed by minors) are interrelated and it allows assuming that both HIVinfection spread and growing crime rate among young people result from unfavorable situation on regional labor markets.

Accomplished cross-sectional studies on correlations between macroeconomic factors and HIV-infection spread usually yield contradictory results, primarily due to variability of examined economic parameters and uninterrupted dynamics of parameters that characterize HIV-infection burden on a given territory (prevalence, morbidity, and mortality). In particular, in some works there are confirmations that average income per capita has its positive influence on morbidity with HIV-infection since an increase in income results in a decrease in morbidity with HIV [10]. But other research works provide evidence that this correlation is inverse since their authors state that higher gross regional product per capita, lower unemployment rate and smaller numbers of people with their incomes below living wage lead to an increase in a number of new HIV cases. At the same time there is a positive correlation between detection of patients with HIV and crime rates. Authors believe it occurs due to specific economic features of drug sales such as a region being rich, available drug distribution networks, and considerable resources of individual consumers; all this results in a growing number of relevant crimes [11].

Economic development of a region, availability of well-paid jobs and social security for unemployed people influence individual labor strategies pursued by economically active population groups. Young people have to start a career at younger ages and are forced to migrate to find a better job; all this leads to wider spread of forced deviant and delinquent behavior practices which, in their turn, make for HIV-infection spread in relevant demographic groups.

Contemporary studies confirm that HIVinfected people more often live in urban areas; it can be explained with a proven correlation between spread of the disease and provision with out-patient polyclinics and greater avail- ability of public healthcare resources, consequently, a greater number of detected diseases cases $[12,13]$.

At the same time this trend may be due to occurring demographic processes such as labor migration by representatives from age and sex groups where HIV is most frequently detected from rural settlements to urban ones [10]; however, we haven't been able to detect any statistically significant correlations with growing migration rate in our research. As it is confirmed by works that focus on examining social and structural parameters of labor migration, young men aged from 25 to 50 tend to prevail among labor migrants in small towns in Russia [14-16]. Most HIV-infected people are also from these demographic groups. Over the last years there has been a growth in a number of infected people among those older than 25. In $200086.7 \%$ HIV-infected people were diagnosed at 15-29 but this share went down to $44.3 \%$ by 2010 . In the first half of $201984.5 \%$ of detected patients with first diagnosed HIV were older than 30. In 2019 HIV-infection was predominantly detected in people aged 30-49 (71.5\% new cases). A share of infected men was significantly higher than a share of infected women in all age groups ${ }^{4}$.

In our research, we detected the strong correlation between HIV prevalence and a number of crimes committed by minors which in its turn was correlated to a number of unemployed people in a region. This correlation may occur due to trends revealed by criminologists in drug trafficking. Overall number of registered crimes committed by minors and related to drug trafficking grew by $28.6 \%$ from 2010 to 2015 [17]. It is partly due to barriers on labor markets and difficulties in finding a job, especially in economically underdeveloped regions. In case there are no barriers to enter a dealer network and available developed intra- and inter-regional relations between organized crime groups who deal with drug trafficking, young people become involved into these criminal circles and commit crimes related to producing, sorting, and taking drugs. Young people participate actively 
not only in producing and selling synthetic substances but also in taking them: a share of young people aged from 14 to 30 amounts to $76 \%$ among drug addicts; a number of young people who take injection drugs is also growing and it results in greater risks of HIVinfection [18-21].

Our research results are consistent with conclusions made by authors who stated that men younger than 35 who lived in urban areas, including those currently or permanently unemployed, took drugs, violated the laws and were prone to risky behavior regarding their health prevailed among HIV-infected patients.

The current situation with growing numbers of HIV-infected people in RF regions and its correlation with social context factors is being discussed in works by social epidemiologists, sociologists, and experts in demography. Partially HIV-infection spread is explained by growing numbers of people in vulnerable population groups and their behavioral peculiarities. Accomplished studies reveal that people who take injection drugs, homosexuals, and commercial sex workers are primary risk groups regarding HIV [22]. At the same time contemporary social and epidemiological trends in HIV spread indicate that over the last years the infection has gone beyond these vulnerable population groups and started to spread actively among overall population ${ }^{6}$ [23]. The process is supported not only by cultural and behavioral peculiarities typical for specific population groups, risky sexual behavior by commercial sex workers and drug addicts [24] but also by specific economic parameters in regions and demographic processes occurring in them.

Conclusion. Existing regional trends in HIV spread in the Russian Federation have apparent differences as per many macrocontext parameters including demographic, socioeconomic, social and political (medical aid availability), and cultural and behavioral ones. Consequences of urbanization create signifi- cant influence on the disease spread since the process is accompanied with a growing share of urban population, unstable labor markets, and growing demands for available free medical aid. We built up the regression model that included relevant regional parameters (specific weight of urban population in total population, a number of unemployed people aged 15-72, provision with out-patient polyclinics per 10,000 people) and it allowed us to reveal that it was exactly these factors that explained $22.0 \%$ of regional differences in a number of patients with first diagnosed HIV.

But at the same time urbanization and intensified labor migration result in changing individual cultural and behavioral strategies including criminal ones and behavioral practices that are health-destructive. The greatest number of crimes committed by young people is registered in cities and this occurs due to pendulum labor migration, as well as contact-free drug distribution and intake becoming more and more popular. Having built the regression model that included a number of registered crimes committed by minors per 100 thousand people we revealed that this factor explained $35 \%$ of regional differences in a number of patients with first diagnosed HIV.

Our results give grounds for assuming that HIV-infection spreads in RF regions primarily due to demographic and socioeconomic parameters and processes that provoke growing influence of specific cultural and behavioral determinants of the disease. Complex effects produced by the aforementioned factors result in apparent regional health inequalities and contribute to persistence of this issue related to morbidity with communicable diseases among population in Russia

Funding. The research was not granted any sponsor support.

Conflict of interests. The authors declare there is no any conflict of interests.

\footnotetext{
${ }^{6}$ Spravka VICh-infektsiya v Rossiiskoi Federatsii v 2017 g. [Reference on HIV-infection in Russia in 2017]. Federal'nyi nauchno-metodicheskii tsentr po profilaktike i bor'be so SPIDom FBUN Tsentral'nogo NII epidemiologii Rospotrebnadzora. Available at: http://aids-centr.perm.ru/images/4/hiv_in_russia/hiv_in_rf_31.12.2017.pdf (March 05, 2021) (in Russian).
} 


\section{References}

1. Link B.G., Phelan J.C. Understanding sociodemographic differences in health - the role of fundamental social causes. American Journal of Public Health, 1996, vol. 86, no. 4, pp. 471-473. DOI: 10.2105/ajph.86.4.471

2. Macintyre S. The black report and beyond what are the issues? Social science \& medicine, 1997 , vol. 44, no. 6, pp. 723-745. DOI: 10.1016/S0277-9536(96)00183-9

3. Cassel J. Social science theory as a source of hypotheses in epidemiological research. American Journal of Public Health and the Nation's Health, 1964, vol. 54, no. 9, pp. 1482-1488. DOI: 10.2105/ajph.54.9.1482

4. Krieger N. Epidemiology and the web of causation: Has anyone seen the spider? Social Science and Medicine, 1994, vol. 39, no. 7, pp. 887-903. DOI: 10.1016/0277-9536 (94) 90202-X

5. Link B.G., Phelan J. Social conditions as fundamental causes of disease. Journal of Health and Social Behavior, 1995, no. 51 (Extra Issue), pp. 80-94.

6. Krieger N. Theories for social epidemiology in the 21st century: an eco-social perspective. International Journal of Epidemiology, 2001, vol. 30, no. 4, pp. 668-677. DOI: 10.1093/ije/30.4.668

7. Leavell H.R. Chronic disease and the behavioral sciences. Journal of chronic diseases, 1955, vol. 2, no. 1, pp. 113-118. DOI: 10.1016/0021-9681(55)90114-4

8. Astrelin A.M. Trends in morbidity, prevalence and mortality from HIV infection and tuberculosis in the regions of Russia in the XXI century. Demograficheskoe obozrenie, 2020, vol. 7, no. 4, pp. 82-107. DOI: 10.17323 /demreview.v7i4.12045 (in Russian).

9. Moran D., Jordaan J.A. HIV/AIDS in Russia: determinants of regional prevalence. International Journal of Health Geographics, 2007, vol. 6, no. 1, pp. 22. DOI: 10.1186/1476-072X-6-22

10. Mekhonoshina N.V., Gudilina N.A., Rostova N.B., Tolstobrova N.A., Faizrakhmanov R.A. An analysis of socioeconomic parameters, related to HIV incidence and HIV-related mortality in the Russian Federation. VICh-infektsiya i immunosupressii, 2017, vol. 9, no. 3, pp. 103-112. DOI: 10.22328/20779828-2017-9-3-103-112 (in Russian).

11. Podymova A.S., Turgel I.D., Kuznetsov P.D., Chukavina K.V. Socio-Economic Factors Determining the Dissemination of HIV infection in the Russian Regions. Vestnik UrFU. Seriya: ekonomika i upravlenie, 2018, vol. 17, no. 2, pp. 242-262. DOI: 10.15826/vestnik.2018.17.2.011 (in Russian).

12. Sokolova E.V., Pokrovskii V.V., Ladnaya N.N. The HIV infection situation in the Russian Federation. Terapevticheskii arkhiv, 2013, vol. 85, no. 11, pp. 10-15 (in Russian).

13. Panova L.V. Accessibility of medical care: Russia in the European context. Zhurnal issledovanii sotsial'noi politiki, 2019, vol. 17, no. 2, pp. 177-190. DOI: 10.17323/727-0634-2019-17-2-177-190 (in Russian).

14. Florinskaya Yu.F. Labor migration from minor Russian towns as a way to survival. Sotsiologicheskie issledovaniya, 2006, no. 6 (266), pp. $79-89$ (in Russian).

15. Mkrtchyan N.V., Florinskaya Yu.F. Socio-economic effects of labor migration from small towns of Russia. Voprosy ekonomiki, 2016, vol. 4, pp. 103-123. DOI: 10.32609/0042-8736-2016-4-103-123 (in Russian).

16. Mkrtchyan N.V. Internal labor migration in Russia: scale and structural characteristics. Nauchnye trudy: Institut narodnokhozyaistvennogo prognozirovaniya RAN, 2016, vol. 14, pp. 546-561 (in Russian).

17. Rad'kova L.S. Uchastie nesovershennoletnikh $\mathrm{v}$ nezakonnom oborote narkoticheskikh sredstv, psikhotropnykh veshchestv ili ikh analogov [Participation of minors in the illicit trafficking of narcotic drugs, psychotropic substances or their substitutes]. Vestnik Voronezhskogo instituta MVD Rossii, 2017, no. 1, pp. 226-233 (in Russian).

18. Efimova A.A. Podrostki i molodezh' v sfere nezakonnogo oborota narkotikov [Teenagers and youth in criminal narcotic trafficking sphere]. Problemy nauki, 2019, vol. 11, no. 47, pp. 65-73 (in Russian).

19. Lelekov V.A., Borodin A.D. Demographic processes and crime. Vestnik Voronezhskogo Instituta FSIN Rossii, 2019, no. 4, pp. 214-218 (in Russian).

20. Lelekov V.A., Kosheleva E.V. Narcocrime and youth. Vestnik Voronezhskogo Instituta FSIN Rossii, 2016, no. 4, pp. 164-168 (in Russian).

21. Kotelnikova O.A. Narcotism as a socially negative phenomenon: a brief criminological analysis. Zakon i pravo, 2019, no. 9, pp. 112-113 (in Russian). 
22. Ladnaya N.N., Pokrovskii V.V., Dement'eva L.A., Sokolova E.V., Aizatulina R.R., Lipina E.S. Razvitie epidemii VICh-infektsii v Rossiiskoi Federatsii v 2017 g. [HIV-infection epidemic development in Russia in 2017]. Aktual'nye voprosy VICh-infektsii. Okhrana zdorov'ya detei s VICh-infektsiei: materialy mezhdunarodnoi nauchno-prakticheskoi konferentsii. St. Petersburg, 2018. Available at: https://congress-ph.ru/common/htdocs/upload/fm/vich/18/may/tezis.pdf\#page=4 (05.03.2021) (in Russian).

23. Pokrovsky V.V., Ladnaya N.N., Pokrovskaya A.V. HIV/AIDS reduces the number of Russians and their life expectancy. Demograficheskoe obozrenie, 2017, vol. 4, no. 1, pp. 65-82 (in Russian).

24. Golodnova S.O., Fel'dblyum I.V., Yurkova L.V., Sarmometov E.V., Nikolenko V.V. Factors that cause contagion and spread of HIV among people from social risk groups. Health Risk Analyses, 2020, no. 4, pp. 130-136. DOI: 10.21668/health.risk/2020.4.15.eng.

Boyarkina S.I., Khodorenko D.K. Societal determinants of HIV-infection spread in regions in the Russian Federation. Health Risk Analysis, 2021, no. 3, pp. 116-126. DOI: 10.21668/health.risk/2021.3.11.eng

Received: 24.03.2021

Accepted: 17.08 .2021

Published: 30.09 .2021 